\title{
Value Relevance of Biological Assets under IFRS
}

\author{
Rute Gonçalves, Universidade do Porto \\ Patrícia Lopes., Universidade do Porto \\ Russell Craig, University of Portsmouth
}

\begin{abstract}
The aim of this paper is to examine the value relevance of fair value accounting of biological assets under IAS 41 - Agriculture - using 389 firm-year observations of listed firms in 27 countries worldwide that had adopted IFRS, for the period between 2011 and 2013. In order to operationalize it as the ability of book value to explain market equity value, this study adjusts the original Ohlson model. The results confirm that recognized biological assets are value relevant at fair value and they are more value relevant in firms that exhibit higher disclosure levels. The same results were obtained when this analysis was conducted for bearer biological assets, but when it was applied to consumable biological assets, the results suggest that investors do not value recognized biological assets in firms that exhibit higher disclosure levels. Bearing in mind the current adjustments to IAS 41, according to which firms will be permitted to choose either the cost or the revaluation models for mature bearer plants under IAS 16 - Property, plant and equipment - for annual periods beginning on/or after 1 January 2016, this paper seeks to help standard setters to better understand the market valuation implications of this standard.
\end{abstract}

Keywords: biological assets, fair value accounting, financial reporting, disclosure index, regulation.

\section{Introduction}

Fair value accounting is an issue widely discussed in the literature (Mala, \& Chand, 2012; Laux, \& Leuz, 2009, Hitz, 2007; Ball, 2006; Cairns, 2006; Barlev, \& Haddad, 2003; Barth, Beaver, \& Landsman, 2001; Holthausen, \& Watts, 2001). Even though fair value is responsible for the volatility of results and for prompting some managerial discretion, it also incorporates more information into financial statements. In order to analyze investors' perceptions of this additional information, it is important to differentiate between recognition and disclosure (Ball, 2006; Kun, 2013; Ahmed, Kilic, \& Lobo, 2006).

In particular, between recognizing and disclosing an amount, both being means to assure the decisionusefulness of financial statement information (Badenhorst, Brümmer, \& de Wet, 2015). In general, and according to Choudhary (2011), recognized values set by managers and revised by auditors have different requirements compared to disclosed values; consequently, investors value recognized values more than disclosed ones. This is particularly useful for standard-setters in order to make decisions regarding recognition and disclosure. Indeed, "standard-setters prioritize financial recognition over disclosure, the empirical evidence on the value relevance of note disclosures is mixed” (Al Jifri, \& Citron, 2009: 123).

Academic research and the intense discussion of fair value are frequently concerned with financial instruments, but IAS 41 requirements of fair valuation extend the debate to the context of agriculture (Argilés, Bladón, \& Monllau, 2011). In particular, "IAS 41 is a 'true' fair value standard: the fair value of biological assets is reported on the firm's balance sheet and any change in the fair value of the biological assets over the reporting period is recognized in the periodic income as an unrealized gain or loss” (Huffman, 2013:2).

In fact, the introduction of fair value in agriculture for all biological assets has led standard setters to depart from previous accounting practices. Some evidence indicates that fair value is more reliable in the decisionmaking process of agents within the agricultural sector (Argilés, Aliberch, \& Blandón, 2012). However, the standardization assured by IAS 41 in this context "does not diminish the fact that the process will still handle a subjective valuation model” (Machado, Martins, \& Carvalho, 2015). In particular, the main disadvantage of fair value is the absence of active markets for some biological assets. In this case, and with regard to the diversity of 
fair valuation models, it is possible for firms to use accounting for their own interests (Gabriel, \& Stefea, 2013). Moreover, Martins, Almeida, \& Jesus (2012) highlight that each biological asset has its own attributes and lifecycles, which also makes the corresponding valuation more difficult.

Based on previous considerations, this study focuses on the following research questions:

- Are biological assets value relevant at fair value under IAS 41?

- Is there a difference in the value relevance of biological assets between listed firms with high and low disclosure levels on biological assets?

In order to address these questions, this study adjusts the original accounting-based valuation model developed by Ohlson (1995) and analyses panel data drawn from a worldwide sample composed of 132 firms from 27 IFRSadopting countries across 8 sectors, focusing on the period between 2011 and 2013. Taking previous studies into consideration, this paper presents extensive research based on a significant number of countries, with recent data concerning a standard that is currently under discussion.

Overall, the results show that the recognized amount of biological assets under the fair value model is value relevant. Additionally, the recognized amount of biological assets under the fair value model is more value relevant for firms that exhibit higher disclosure levels. After splitting the sample according to IAS 41's two classes of biological assets, namely, bearer biological assets and consumable assets, the same results were obtained for bearer biological assets. As far as consumable biological assets are concerned, it seems that investors value recognized biological assets, but independently from the corresponding disclosure level.

The paper is structured as follows: Section 2 describes the regulatory framework of IAS 41. Section 3 provides a review of the literature, firstly related to the discussion of fair value accounting in international financial reporting, and then regarding non-financial assets and biological assets in particular. Section 4 introduces the hypotheses. Section 5 describes the methodology, presents the sample and the research model, and then explains the disclosure index. Section 6 discusses the findings of the empirical analysis. Lastly, the final section provides a brief conclusion.

\section{Regulatory framework of IAS 41}

IAS 41 was originally issued in December 2000 and first applied to annual periods beginning on or after January 1, 2003. This standard prescribes the accounting treatment for biological assets during the period of biological transformation and for the initial measurement of agriculture produce at the point of harvest.

As a simple rule, IAS 41 requires biological assets to be measured on initial recognition and at subsequent reporting dates at fair value less costs to sell. Moreover, the single exception allowed to fair value measurement is only applied to initial recognition and in a particular context: a market-determined price is not available and the entity cannot assure a reliable estimate of fair value [IAS 41.30]. In such conditions, the entity uses the unreliability clause of fair value and recognizes the biological assets at cost less depreciation and impairment. In addition, agricultural produce should be measured at fair value less costs to sell at the point of harvest.

According to this standard, biological assets can be divided into bearer biological assets and consumable biological assets. In terms of the market valuation implications of this standard, fair value assessment diverges under such a classification. Unlike agricultural produce, bearer biological assets are self-regenerating (e.g. livestock from which milk is produced, grape vines, fruit trees, and trees from which firewood is harvested while the tree remains) [IAS 41.44]. Conversely, consumable biological assets are harvested as agricultural produce or sold as biological assets (e.g. livestock intended for the production of meat, livestock held for sale, fish in farms, crops such as maize and wheat, and trees grown for lumber) [IAS 41.44]. There is often an active market for this class of biological asset, and the corresponding fair value can thus be easily determined.

Recently, the IASB (International Accounting Standards Board) has amended this standard in relation to bearer plants. In this context, a bearer plant is a living plant that is used in the production or supply of agricultural produce; is expected to bear produce for more than one period; and has a remote likelihood of being sold as agricultural produce, except for incidental scrap sales. These amendments are effective for annual periods beginning on or after 1 January 2016 and take into consideration bearer plants (prior to reaching maturity), their measurement at accumulated cost, such as self-constructed items of property, plants and equipment. Additionally, entities will be permitted to choose either the cost model or the revaluation model for mature bearer plants under IAS 16. Produce growing on bearer plants should be accounted for at fair value in accordance with IAS 41. 


\section{Literature review}

\subsection{Fair value accounting under International Financial Reporting Standards (IFRS)}

In general, value relevance research infers how accounting information is reflected in share prices and influences the decision-making of investors (Barth, Beaver, \& Landsman, 2001). Incorporating more information into financial statements seems to be the most important advantage of fair value accounting according to several authors (Mala, \& Chand, 2012; Ball, 2006; Barlev, \& Haddad, 2003; Barth, Beaver, \& Landsman, 2001). In particular, fair value covers more information than historical cost whenever there is either an observable market price that the manager cannot adjust or an independently observable and reliable estimate of market price (Ball, 2006).

Nonetheless, there are also some well-known disadvantages related to fair value accounting. The recognized fair value changes in capital or in profit and loss are responsible for the higher volatility of reported results, hiding the value creation process (Mala, \& Chand, 2012). Furthermore, when a liquid market price is not available, "mark to market" accounting leads to "mark to model" accounting, with several valuation models, such as the present value (discounted cash flow) method and the methods adapted from the original Black-Scholes model (Black, \& Scholes, 1973). These fair value models are based on specific parameters and assumptions that could lead to management manipulation (Mala, \& Chand, 2012; Hitz, 2007; Ball, 2006). In fact, regarding fair value measurement, Fargher, \& Zhang (2014) state that when accounting standards allow managerial discretion, this opportunity may be in practice used unscrupulously by managers possibly compromising the relevance of financial reporting.

According to Barlev, \& Haddad (2003), fair value accounting is employed in three domains: financial instruments (with easy access to market price), investment property (with feasible future cash flow estimation) and agriculture. For agriculture, expectations have been high regarding the existence of a highly developed future and active market its products. Nevertheless, for non-financial assets, such as investment property and biological assets, a market price is not always available, which makes a fair value assessment more difficult.

\subsection{Fair value accounting of non-financial assets}

In the context of biological assets, Lefter, \& Roman (2007:15) argue that "the transformation process is immediately represented in the financial statements and then the investor has the possibility of estimating the future economic benefit”. The following papers discuss the impact of fair value accounting and report mixed results.

Martins, Almeida, \& Jesus (2012), using a sample of 45 firms for 2008 conclude that fair value accounting for biological assets is not value relevant for investors, who are more interested in the financial performance of firms as a whole. Conversely, by conducting an experiment involving students, farmers and accountants engaged within the agricultural sector in Spain, Argilés, Aliberch, \& Blandón (2012) compare the constraints that arise from measuring using each of the two valuation methods for biological assets, namely historical cost and fair value. The findings suggest that fair value is more useful in the decision-making process of agents in the agricultural sector. Moreover, fair value seems to be more suitable for accounting preparation than historical cost. In contrast, Argilés, Bladón, \& Monllau (2011:106) suggest "given (that) market prices present pronounced fluctuations in the agricultural sector, less reliable accounting under FV (fair value) would be expected”. Based on 347 Spanish firms from 1995 to 2006, and considering the importance of random factors derived from climate and market conditions in agriculture, the empirical evidence does not suggest any difference in the relevance of accounting information from either valuation method, in the sense that fair value is not responsible for higher unpredictability and volatility for future earnings and cash flows.

Carrying out a study based on 25 listed firms from Brazil for 2008 and 2009, Silva Filho, Machado, \& Machado (2013) conclude that measurement of biological assets using fair value rather than historical cost was not relevant to users of accounting information. Conversely, Silva Filho, Martins, \& Machado (2013) argue that both historical cost and fair value measurements of biological assets are relevant to the Brazilian capital market. Additionally, it is noteworthy that replacing historical cost with fair value when measuring such assets was beneficial to the market, from an informational point of view, since the difference between the estimated market value and accounting numbers decreased.

In contrast to the above academic discussion concerning asset measurement which focuses exclusively on fair value or historical cost, Huffman (2013) examines whether asset measurement related to asset use assures more value relevant information to investors. Regarding generated value, an asset can be classified as an in-exchange asset, which represents a consumable biological asset (for example, a plantation to produce timber logs) or as an in-use asset, which represents a bearer biological asset (for example, a plantation to produce palm oil). Previously, Littleton (1935) stated that the information is more relevant for investors if fair value is applied to in-exchange 
assets and historical cost is applied to in-use assets. Based on a sample of 183 international firms from 35 countries that adopted IAS 41 for the periods 1999-2001 and 2007-2010, Huffman (2013) concludes that book value and earnings information is more value relevant when consumable biological assets are measured at fair value and bearer biological assets are measured at historical cost.

Since little research has been carried out on fair value accounting with regard to biological asset measurement and the scope of such studies has been narrow, generally focusing on comparisons between historical cost and fair value, this paper also relied on literature dealing with other types of non-financial assets (Baboukardos, \& Rimmel, 2014; Hamberg, \& Beisland, 2014; Tsoligkas, \& Tsalavoutas, 2011; Lourenço, \& Curto, 2008), such as goodwill, investment property, research and development expenditure. In order to test market valuation implications, all papers apply the same methodology, an adaptation of the Ohlson model (Ohlson, 1995), further explained in section 5 (with the exception of Hamberg, \& Beisland (2014), who adopt a return model). A key message of these papers is that non-financial assets are value relevant, and sometimes this evidence occurs independently of country classification (common law or code law). For example, Baboukardos, \& Rimmel (2014) argue that accounting treatment of purchased goodwill under IFRS is more sensitive in code-law countries, given their higher constraints for dealing with fair value accounting. Based on 76 Greek firms, their study shows relevant accounting numbers in fair value accounting in firms that act in strong accordance with IFRS disclosure requirements. Using a sample of 224 European firms, Lourenço, \& Curto (2008) argue that investors differentiate the recognized cost and fair value and the disclosed fair value of investment property. However, they do not differentiate between valuation implications of recognized fair value in Germany, in the United Kingdom (the extreme examples of Continental and Anglo-Saxon models, respectively), France and Sweden (both countries with a medium level of shareholder protection). Some papers suggest that the corresponding mandatory disclosure is also a disciplinary element of perception of the market (Baboukardos, \& Rimmel, 2014). Moreover, in the absence of a market price, managers usually act in self-interest. For example, Hamberg, \& Beisland (2014) show that contrary to the period prior to IFRS adoption, impairments and stock returns in Sweden are no longer statistically related under IFRS 3. A possible explanation is that impairment could be perceived as a decreased value by market participants when this impairment occurs in addition to amortizations. In this respect, managers are motivated to prevent the impairment of goodwill. Furthermore, Tsoligkas, \& Tsalavoutas, (2011) investigated whether the transition to IFRS had implications on the valuation of R\&D expenditure in the United Kingdom. Their results suggest a positive (negative) and significant association between capitalized (expensed) R\&D and market values. Moreover, R\&D expenses are negatively value relevant only for large firms. Therefore, IFRS are capable of informing investors as to whether research expenditure indicates expenses on non-successful projects that will not assure future benefits for the firm.

In brief, in comparison to previous value relevance studies related to biological assets (Martins, Almeida, \& Jesus, 2012; Argilés, Aliberch, \& Blandón, 2012; Argilés, Bladón, \& Monllau, 2011; Silva Filho, Machado, \& Machado, 2013; Silva Filho, Martins, \& Machado, 2013; Huffman, 2013), the present study tests the value relevance of recognized biological assets at fair value (instead of considering both types of valuation method, historical cost and fair value). Following research into other non-financial assets (Baboukardos, \& Rimmel, 2014; Lourenço, \& Curto, 2008) this study also includes the disclosure effect.

\section{Development of hypotheses}

Based on previous research, the present study tests the value relevance of recognized biological assets at fair value. This first research question examines the ability of biological assets to explain market equity values.

In previous literature concerning biological assets, although there are studies which confirm that accounting information related to biological assets impacts on the decision-making of investors (Argilés, Aliberch, \& Blandón, 2012; Argilés, Bladón, \& Monllau, 2011; Silva Filho, Martins, \& Machado, 2013), there are other studies that do not support value relevance as far as biological assets are concerned (Martins, Almeida, \& Jesus, 2012; Silva Filho, Machado, \& Machado, 2013). Given this mixed empirical evidence, there is no strong expectation regarding the sign of the first hypothesis:

\section{H1: Biological assets are value relevant at fair value under IAS 41.}

In order to explore investors' perceptions regarding the incorporation of more information into financial statements, as explained above, it is important to differentiate recognition from disclosure (Al Jifri, \& Citron, 2009; Kun, 2013; Ball, 2006; Ahmed, Kilic, \& Lobo, 2006).

Given the conceptual framework of the IASB (International Accounting Standards Board), disclosure is not a substitute for recognition. To be recognized an item must have "a cost or value that can be measured with reliability” (paragraph no. 4.38.b), IASB Conceptual Framework). The same criteria are not applied for disclosed items. In this respect, and by analogy to the FASB (Financial Accounting Standards Board), investors characterize 
recognized items as more reliable than disclosed items (Fried, 2012). Nonetheless, Choudhary (2011) and Holthausen, \& Watts (2001) argue that recognition suggests less reliability, since managers are more encouraged to manipulate recognized items than disclosed items. There are also other arguments that support a distinction between the two, such as investors incorrectly underestimating disclosed items through lack of expertise or due to the cost of processing information (Al Jifri, \& Citron, 2009; Kun; 2013). Conversely, the efficient market hypothesis suggests that "recognition adds little when the information investors seek is disclosed" (Barth, Clinch, \& Shibano, 2003: 582).

In the context of the present study, introduction of the disclosure effect is justified for the following reasons: first, given the controversial nature of the current debate outlined above; second, in order to add to previous value relevance studies that have dealt only with recognition of biological assets (Huffman, 2013). Based on a survey of biological assets in Australia, the United Kingdom and France, Elad, \& Herbohn (2011) concluded that there is a lack of comparability between disclosure practices, with French firms tending to disclose less information on biological assets. Given the diverse nature of behavior regarding the disclosure level of biological assets, a different impact on market valuation can be predicted. With this in mind, a positive signal is expected for the second hypothesis:

H2: The value relevance of biological assets is higher in listed firms with high disclosure levels on biological assets.

The research model includes market value per share (MV) as the dependent variable, which corresponds to the month-end market price (three months after the fiscal year. ${ }^{1}$ ), and analyses several factors that are expected to affect it, namely, book value per share, biological assets per share, earnings per share, disclosure index ranking with respect to IAS 41 and two control variables, firm size and sector.

Book value per share (BV) is the proportioned common equity divided by outstanding shares at the firm's fiscal year-end (WS05476) with a positive signal expected. Biological assets per share (BA) corresponds to a ratio between biological assets (given by the variables WS18277 - net book value, WS18278 - gross or WS18258 current) and common shares outstanding (WS05301) with no signal expected. Earnings per share (E) represents the net income available to common equity that is used by the firm to calculate its earnings per share (WS01401), divided by common shares outstanding (WS05301) with a positive signal expected. Disclosure index ranking (Dindex) is a dummy variable coded one if the disclosure index regarding the biological assets of each firm is below the first quartile, coded two if it stands between the first and third quartiles, and coded three if it is above the third quartile of the disclosure index distribution of the sample, with a positive signal expected. The annual reports of each firm during the period between 2011 and 2013 were analyzed in order to calculate the disclosure index $^{2}$. The control variables are firm size (SIZE) and sector (SECTOR), with a positive signal expected. Previous literature measures firm size (SIZE) in different ways. In this paper, firm size corresponds to the logarithm of total assets (WS02999). Finally, sector (SECTOR) refers to SIC - code classification (2-digit division), namely: sector 1 - agriculture, forestry, fishing and mining (01-14), sector 2 - manufacturing (20-39), and other sectors. ${ }^{3}$ The introduction of these two variables to control for any potential effects of certain firm characteristics is supported by literature regarding value relevance of other non-financial assets for size (Tsalavoutas, \& Dionysiou, 2014) and for sector (Dahmash, Durand, \& Watson, 2009; Hamberg, \& Beisland, 2014).

\section{Methodology}

\subsection{Sample}

This study includes panel data drawn from a sample of $3894^{4}$ firm-year observations of listed firms that had adopted IFRS until 2010, across 27.5 countries and 8 different sectors, during the period between 2011 and 2013.

\footnotetext{
${ }^{1}$ Since the fiscal year-end differs among the firms in the sample ( $31^{\text {st }}$ March, $30^{\text {th }}$ April, $31^{\text {st }}$ May, $30^{\text {th }}$ June, $31^{\text {st }}$ August, $30^{\text {th }}$ September, $30^{\text {th }}$ November and $31^{\text {st }}$ December), the market value per share (MV) variable was set according to these dates (WS05040 - June, WS05045 - July, WS05050 - August, WS05055 - September, WS05065 - November, WS05070 - December, WS05020 - February and WS05025 - March). For example, WS05040 - market price June close corresponds to market value per share three months after fiscal year end on $31^{\text {st }}$ March.

${ }^{2}$ This examination was performed by one coder. To minimise possible coding bias, the researcher coded the information twice, thus resolving any discrepancies.

3 The number of instances of “Others” as a sector is presented as follows: Wholesale trade (7), Transportation, \& pub. utilities (6), Retail trade (5), Finance, insurance, \& real estate (2), Services (2) and Construction (1).

${ }^{4}$ Seven firm-year observations are missing, as well as six observations regarding the market value per share variable (the corresponding data is not available in Datastream). In addition, one observation was removed from the earnings per share variable because it was identified as an outlier (further explained in section 6.2.).

${ }^{5}$ The countries are Australia, Belgium, Brazil, Chile, Cyprus, Denmark, Finland, France, Germany, Greece, Hong Kong, Ireland, Italy, Kenya, Lithuania, Netherlands, New Zealand, Norway, Papua New Guinea, Peru, Philippines, Portugal, South Africa, Spain, Sweden, Ukraine and
} 
The sample contains different amounts of both recognized biological assets in the face of financial statements and disclosed information in the notes of financial statements under fair value measurement.

According to Gastón, García, Jarne, \& Laínez Gadea (2010), there are some exceptions and exemptions allowed by IFRS 1 - First-time Adoption of International Financial Reporting Standards - which may cause some constraints when analyzing and making inferences about information on the year of adoption. As a consequence, 2010 was defined as the limit year for considering firms that had adopted IFRS (or equivalent standards). The data was collected in Datastream. Firstly, countries that had adopted IFRS until 2010 were selected. Secondly, firms with biological assets were then selected from the corresponding sample of countries, resulting in 164 firms. The criteria was to follow one of the biological asset variables (WS18277 - net book value; WS18278 - gross, WS18258 - current) and assure that each firm had biological assets in the entire period between 2011 and 2013. Finally, thirty firms under historical cost valuation and two firms without an available annual report were removed. The total sample corresponds to 132 firms.

\subsection{Research model}

In general, value relevance research examines the association between accounting amounts and equity market values. According to Barth, Beaver, \& Landsman (2001), the choice of which methodology to adopt depends on the research question and the corresponding hypothesis as well as econometric considerations. Price models stock price regressed on earnings per share - analyse what is reflected in firm value, while return models - returns regressed on scaled earnings variables - analyse what is reflected in changes in value over a specific period of time. This study examines the value relevance of biological assets, by adopting a price model and adjusting the original accounting-based valuation model developed by Ohlson (1995). In general, this model represents firm value as a linear function of book value of equity and earnings per share. Regarding non-financial assets, such as goodwill, investment property and tangible and intangible assets, this approach was also followed by several studies (Baboukardos, \& Rimmel, 2014; Oliveira, Rodrigues, \& Graig, 2010; Lourenço, \& Curto, 2008; Tsoligkas, \& Tsalavoutas, 2011; Barth, \& Clinch, 1998). Additionally, and regarding the purpose of the present research, Martins, Almeida, \& Jesus (2012) adopted this approach with regard to biological assets, arguing that this model can effectively measure the sensitivity and cause and effect between the book value and the market value of a given firm. Finally, the incorporation of disclosure in the value relevance of goodwill is also tested with this valuation model (Baboukardos, \& Rimmel, 2014, Al Jifri, \& Citron, 2009).

Furthermore, the Ohlson model is more explicit for this context, considering the research questions introduced in this paper. The focus is on financial statement amounts, in particular, biological assets. Consequently, and according to Barth, \& Clinch (1998), this model analyses the market price as a summary measure of relevant information to investors and explores the ability of recognized financial statement amounts to explain this measure; in this case the book value is split from the effect of biological assets.

This study submitted the dataset under a random effect model (Greene, 2012). The Hausman test was then applied, in which the null hypothesis shows that the coefficients estimated by the random effect estimator are the same as those estimated by the fixed effect estimator. The results infer that a fixed effect model is the appropriate model for this sample. By following the panel least squares method, three equations are considered for the adjusted Ohlson model (Ohlson, 1995). The results are provided in table 3. In these regressions, the presence of heteroscedasticity is taken into account with White diagonal standard errors and covariance (White, 1980). Additionally, and in order to reduce heteroscedasticity, all the variables (except control variables) are deflated by the number of common shares outstanding (Barth, \& Clinch, 2009). A return model could be used in a complementary study to investigate whether annual share returns are associated with current-year revaluations (Barth, \& Clinch, 1988), though it would necessitate splitting firm earnings from the unrealized valuation gains/losses of biological assets. This information was analysed in DataStream even though a significant number of values are missing with respect to the firms in the selected sample.

In brief, value relevance of recognized biological assets is tested in a regression where a firm's market value is a function of the book value of equity and earnings. This relation is tested in the first equation with market value per share (MV) as the dependent variable, and book value per share (BV) and earnings per share (E) as the independent variables. Moreover, this first model includes two control variables, namely, the firm's size (SIZE) and the sector where it belongs (SECTOR).

$M V_{i t}=b_{0}+b_{1} B V_{i t}+b_{2} E_{i t}+b_{3} S I Z E_{i t}+b_{4} \sum^{j=1,2,3} S E C T O R_{j i t}+u_{i t}$

In order to test the first hypothesis, in the second model the variable book value per share (BV) is then divided into two variables, namely book value per share excluding biological assets per share (BV-BA), and biological 
assets per share (BA). The coefficient $b_{2}$ assures response to the value relevance of biological assets under IAS 41.

$M V_{i t}=b_{0}+b_{1}(B V-B A)_{i t}+b_{2} B A_{i t}+b_{3} E_{i t}+b_{4} S I Z E_{i t}+b_{5} \sum^{j=1,2,3} S E C T O R_{j i t}+u_{i t}$

Finally, and with regard to the second hypothesis, the third model adds the effect of disclosure. In this case, the aim is to investigate whether there is a systematic difference in biological asset valuation effects between firms with relatively high and relatively low disclosure levels of biological assets. The coefficient $b_{5}$ assures a response to the value relevance of biological assets regarding mandatory and voluntary disclosure. As previously explained, Dindex is a dummy variable based on whether the disclosure index regarding the biological assets of each firm is below the first quartile, in the middle of both quartiles, or above the third quartile of the sample's disclosure index distribution.

$M V_{i t}=b_{0}+b_{1}(B V-B A)_{i t}+b_{2} B A_{i t}+b_{3} E_{i t}+b_{4} \sum^{j=1,2,3} \operatorname{Dindex}_{j i t}+b_{5} \sum^{j=1,2,3} \operatorname{Dindex}_{j i t} \times B A_{i t}+b_{6} S I Z E_{i t}+b_{7} \sum^{j=1,2,3} S_{E C T O R}+u_{i t}(4)$

\subsection{Disclosure index}

Given the disclosures required by IAS 41, a disclosure index was structured and calculated with the notes of consolidated financial statements included in the annual report of this sample of firms for the period between 2011 and 2013. This index is divided into three sections: mandatory items, non-mandatory but recommended items (both sections represent all disclosure items required by IAS $41^{6}$ ) and non-mandatory and non-recommended items (this section corresponds to voluntary information demonstrating that firms exceed the mandatory information). The last category is constructed according to the international report regarding the impact of adopting IAS 41 in the timber sector developed by PWC (2011). Three topics are identified as being followed by clients in disclosure practices regarding the timber sector, namely: revealing the complexity of valuation parameters, although there is limited information regarding the effect on the valuation; providing more information on the effects of variations in key valuation factors; exposing firm assumptions on future prices and costs, as well as disclosing a sensitivity analysis with multiple parameters.

Based on the literature (Santos, Ponte, \& Mapurunga, 2013; Lopes, \& Rodrigues, 2007; Owusu-Ansah, 1998), the disclosure index is dichotomous, unweighted and adjusted for non-applicable items, which means that: firstly, a score of one is assigned to an item if it is disclosed, or zero if it is undisclosed; secondly, each item is given equal importance in all three categories; and thirdly, items with no information in the notes about any disclosure items from IAS 41 are excluded. Regarding the latter point, the only exemption allowed is in accordance with the following clause in IAS 41 [IAS 41.49]: "financial risk management strategies related to agricultural activity". Risk strategy related to biological assets is highly important in the sense that a firm is obliged to declare its overall strategy in the annual report. Therefore, if this item contains no information it is considered in the index to be a non-disclosed item. The maximum number of items in the disclosure index is $27^{7}$.

Consequently, the total score of the mandatory and voluntary disclosure index for biological assets (Index) in a firm is:

$$
\operatorname{Index}_{i}=\sum_{i=1}^{m} d_{i} / m
$$

where $d_{i}=0$ or 1 , as follows: $d_{i}=1$ if the item is disclosed and $d_{i}=0$ otherwise; $m=$ maximum number of applicable items a firm may disclose.

\footnotetext{
${ }^{6}$ In order to construct the disclosure index, the disclosure items from IAS 41 that focus on historical cost were omitted.

${ }^{7}$ According to (EU) Commission Regulation no. 1255/2012 of 11 December 2012, IFRS 13 - Fair value measurement is applied when another IFRS requires or permits fair value measurement or disclosures about fair value measurements. Therefore, this standard sets out amendments in several standards, such as in IAS 41, by deleting paragraphs 47 and 48 . An entity shall apply the amendments for annual periods beginning on or after 1 January 2013. Therefore, the disclosure score, for 2013 in particular, is 27 or 25, respectively.
} 


\section{Results}

\subsection{Descriptive analysis}

Table 1 presents the descriptive statistics for the variables. Market price per share (MV), book value per share (BV), biological assets per share (BA) and the disclosure index (Index) present a wide range ${ }^{8}$ of results Given the fact that the annual report of each firm was analyzed in order to calculate the disclosure index, the biological assets presented in the balance sheet and in the notes of the financial statements were compared to the information obtained by DataStream to additionally validate the study and, in certain cases, to provide missing values to this variable. The analysis excludes any attempt to identify and remove outliers in the case of biological assets per share. Since this is the main variable to determine the number of firms in the sample, the decision was made to retain all firms with biological assets, regardless of their materiality.

\begin{tabular}{|c|c|c|c|c|c|c|}
\hline Variable & Mean & Median & Maximum & Minimum & Std. Dev. & \\
\hline$M V$ & 7.62 & 1.41 & 126.53 & 0.01 & 16.19 & \\
\hline$B V$ & 6.59 & 1.59 & 148.13 & -0.47 & 15.68 & \\
\hline$B V-B A$ & 4.89 & 1.23 & 92.10 & -1.64 & 11.59 & \\
\hline$B A$ & 1.70 & 0.16 & 56.68 & $0.0(1)$ & 5.94 & \\
\hline$E$ & 0.50 & 0.06 & 13.88 & -13.08 & 1.86 & \\
\hline SIZE & 5.84 & 5.74 & 7.42 & 3.96 & 0.76 & \\
\hline \multirow[t]{2}{*}{ Index } & 0.60 & 0.60 & 1.00 & 0.13 & 0.18 & \\
\hline & Frequency & Percent & & & Frequency & Percent \\
\hline SECTOR & & & \multicolumn{4}{|l|}{ Dindex } \\
\hline Manufacturing & 63 & 47.73 & \multicolumn{2}{|c|}{ Below quartile 0.25 (0.50) } & 98 & 24.75 \\
\hline $\begin{array}{l}\text { Agriculture, forestry, } \\
\text { fishing and mining }\end{array}$ & 46 & 34.85 & \multicolumn{2}{|c|}{$\begin{array}{l}\text { Between quartiles } 0.25(0.50) \\
\text { and } 0.75(0.74)\end{array}$} & 202 & 51.01 \\
\hline Others & 23 & 17.42 & \multicolumn{2}{|c|}{ Above quartile $0.75(0.74)$} & 96 & 24.24 \\
\hline Total & 132 & 100.00 & \multicolumn{2}{|l|}{ Total } & 396 & 100.00 \\
\hline
\end{tabular}

Concerning the disclosure index, untabulated findings reveal that the most frequently reported item is: “A reconciliation of changes in the carrying amount of biological assets between the beginning and the end of the period" (n=368; [IAS 41.50]). This evidence is supported by Silva, Figueira, Pereira, \& Ribeiro (2012) for Brazilian firms. Furthermore, the least reported item is: "An aggregate gain or loss arising during the period on initial recognition of biological assets" (n=9; [IAS 41.40]). Taking into consideration the disclosures that exceed the mandatory and recommended items, this may suggest that there is an opportunity for improving biological asset disclosure, as concluded by PWC (2011) for the timber sector.

Analysing the ranking of countries by the number of firms and by the average disclosure level in the period between 2011 and 2013, untabulated findings show some discrepancy of information between firms and some lack of compliance regarding IAS 41. For example, Hong Kong, Australia and Brazil are represented by 22, 16 and 15 firms, respectively, and the corresponding average disclosure level is around 0.6 in each year of the sample. Germany and Belgium are only represented by one firm and the corresponding average disclosure level is around 0.8. In order to better understand this finding and ensure further improvements, a recent report developed by Tsalavoutas, André, \& Dionysiou (2014) provides some recommendations for other non-financial assets. Based on a sample of 544 firms worldwide for the financial year 2010-2011, one aim of this research was to examine the level of compliance with mandated disclosures concerning mergers and acquisitions, intangibles and impairment assets. Overall, the study concludes that information between firms diverges considerably and that there is some level of non-compliance with regard to these three standards. The advice from the report is to discover whether firms deliberately do not make certain transactions material enough; whether the standards are clear enough; or whether firms intentionally fail to follow mandatory disclosure requirements. Therefore, preparers, regulators and enforcement bodies need to focus on improving the extent of firms' disclosures and to

\footnotetext{
${ }^{8}$ There are four firms with a negative book value (and as a consequence, the variable (BV) is negative). The corresponding data was not removed, given the fact that all these firms are still in activity, without any bankruptcy context. There are also four firms with a higher amount of biological assets compared to book value, which justifies the negative minimum value in the variable (BV-BA).
} 
eliminate ambiguity in the interpretation of standards in order to assure greater comparability of information provided by firms.

Table 2 displays Pearson's rank correlation coefficients below the diagonal, and Spearman's rank correlation coefficients above the diagonal. Both sets of correlations show that all the independent variables are correlated positively with stock price. In particular, the variables (BV) and (BV-BA) are highly positively correlated with the dependent variable. Regarding the first hypothesis, the correlation coefficient of the BA variable is a preliminary signal that biological assets are value relevant on a univariate basis. In multivariate analyses, it is frequently accepted that correlations between independent variables are not risky unless they exceed 0.80 or 0.90 (Gujarati, 1995). The correlation coefficients are higher than 0.90 for the BV and BV-BA variables, but this has no effect on the analysis because both variables are not used in the same regressions.

Table 2. Correlations (Pearson/Spearman)

\begin{tabular}{lrrrrrr}
\hline & $M V$ & $B V$ & $B V-B A$ & $B A$ & $E$ & $S I Z E$ \\
\hline$M V$ & & $\mathbf{0 . 9 3 4}$ & $\mathbf{0 . 8 8 9}$ & $\mathbf{0 . 6 5 8}$ & $\mathbf{0 . 7 5 4}$ & $\mathbf{0 . 5 6 6}$ \\
$B V$ & $\mathbf{0 . 8 8 7}$ & & $\mathbf{0 . 9 5 5}$ & $\mathbf{0 . 7 3 3}$ & $\mathbf{0 . 6 8 7}$ & $\mathbf{0 . 5 1 1}$ \\
$B V-B A$ & $\mathbf{0 . 8 1 2}$ & $\mathbf{0 . 9 4 9}$ & & $\mathbf{0 . 5 8 4}$ & $\mathbf{0 . 6 5 6}$ & $\mathbf{0 . 4 9 6}$ \\
$B A$ & $\mathbf{0 . 7 5 7}$ & $\mathbf{0 . 7 8 9}$ & $\mathbf{0 . 5 5 4}$ & & $\mathbf{0 . 4 5 4}$ & $\mathbf{0 . 3 1 6}$ \\
$E$ & $\mathbf{0 . 7 8 7}$ & $\mathbf{0 . 7 3 3}$ & $\mathbf{0 . 6 4 2}$ & $\mathbf{0 . 6 8 2}$ & & $\mathbf{0 . 4 2 1}$ \\
$S I Z E$ & $\mathbf{0 . 3 0 4}$ & $\mathbf{0 . 2 4 5}$ & $\mathbf{0 . 2 9 7}$ & 0.067 & $\mathbf{0 . 1 8 0}$ & \\
\hline
\end{tabular}

Correlations in bold indicate statistical significance at $1 \%$ level

\subsection{Research model}

Table 3 shows the estimated coefficients of the panel least square regressions for the three models. Overall, the adjusted $\mathrm{R}^{2}$ of models 1,2 and 3 confirms that when biological assets and the corresponding disclosure level are introduced separately, the explanatory power of the model improves, albeit only slightly.

\begin{tabular}{|c|c|c|c|c|c|c|}
\hline \multirow[b]{2}{*}{ Variables } & \multicolumn{2}{|c|}{ Model 1} & \multicolumn{2}{|c|}{ Model 2} & \multicolumn{2}{|c|}{ Model 3} \\
\hline & Coef. & SE & Coef. & SE & Coef. & SE \\
\hline Constant & -10.499 & $2.943^{* * *}$ & -11.774 & $2.457^{* * *}$ & -10.270 & $2.599^{* * *}$ \\
\hline$B V$ & 0.668 & $0.119 * * *$ & & & & \\
\hline$B V-B A$ & & & 0.596 & $0.122^{* * *}$ & 0.668 & $0.158^{* * *}$ \\
\hline$B A$ & & & 0.881 & $0.274^{* * *}$ & 0.507 & $0.298^{*}$ \\
\hline$E$ & 2.608 & $1.080^{* *}$ & 2.406 & $1.062^{* *}$ & 2.432 & $0.948^{* *}$ \\
\hline Dindex $_{1}$ & & & & & 1.212 & 0.855 \\
\hline Dindex $_{3}$ & & & & & -0.622 & 0.505 \\
\hline Dindex $_{1} \times B A$ & & & & & 1.402 & 1.537 \\
\hline Dinde $_{3} \times B A$ & & & & & 0.797 & 0.258 *** \\
\hline \multicolumn{7}{|l|}{ Controls } \\
\hline SIZE & 1.963 & $0.523^{* * *}$ & 2.258 & $0.394^{* * *}$ & 1.863 & $0.402^{* * *}$ \\
\hline SECTOR $1+S E C T O R 2=1$ & 1.136 & 0.887 & 0.711 & 0.838 & 0.881 & 0.855 \\
\hline$N$ & \multicolumn{2}{|c|}{389} & \multicolumn{2}{|c|}{389} & \multicolumn{2}{|c|}{389} \\
\hline F-stat & \multicolumn{2}{|c|}{$327.428^{* * *}$} & \multicolumn{2}{|c|}{$287.464^{* * *}$} & \multicolumn{2}{|c|}{$213.358^{* * *}$} \\
\hline Adj. $R^{2}$ & \multicolumn{2}{|c|}{0.835} & \multicolumn{2}{|c|}{0.838} & \multicolumn{2}{|c|}{0.858} \\
\hline
\end{tabular}

In model 1, book value per share (BV) and earnings per share (E) are statistically and positively significant. Therefore, this result infers that both variables are associated with the firms' market value. In order to test the first hypothesis, model 2 excludes biological assets per share (BA) from book value per share (BV). Book value excluding biological assets per share (BV-BA), biological assets per share (BA) and earnings per share (E) are statistically and positively significant. Hence, this data confirms the first hypothesis. Regarding the second hypothesis, model 3 tests whether there is a difference in the value relevance of biological assets between listed firms with high and low disclosure levels on biological assets. This regression includes the interaction variable between the dummy variable related to the disclosure level (Dindex) and biological assets per share (BA). Book value excluding biological assets per share (BV-BA), biological assets per share (BA), earnings per share (E) and 
the interaction variable (Dindex $x_{3}$ BA) are statistically and positively significant. Therefore, this data confirms the second hypothesis.

In order to provide some robustness tests, three additional analyses were conducted. Firstly, untabulated findings reveal that the inferences of these equations are not sensitive to using prices as of three or six months after fiscal year-end, except in the third model. In this case, the interaction variable is not statistically significant when considering price as of six months after fiscal year-end. Secondly, and given the fact that biological assets per share displays a wide range of values, model 2 and model 3 were re-estimated, using a sub-sample in which firms below the $25^{\text {th }}$ percentile in terms of biological assets intensity in the sample are excluded. Untabulated findings show that the results are the same. Thirdly, the sample was divided according to the biological asset classifications under IAS 41, namely bearer and consumable biological assets. The third model was re-estimated using these two sub-samples. Table 4 displays the corresponding results.

The estimated coefficients of the sub-sample of bearer biological assets are statistically similar to those of the initial multivariate analysis. In the case of consumable biological assets, the interaction variable is not supported; therefore, it seems that investors do not value recognized biological assets in firms that exhibit higher disclosure levels. Usually there is an available market price for consumable biological assets and they are often sold in the short term. Therefore, the fair value of consumable biological assets is captured by the market faster than for bearer biological assets. Moreover, bearer biological assets are held for an extended period and typically it is more difficult to access the corresponding fair value. Consequently, in this case, mandatory disclosure or any further information is useful, and for that reason investors value bearer biological assets for firms that exhibit higher disclosure levels of biological assets. In order to reinforce the above analysis, the Chow test was used to determine whether the coefficients can differ across subgroups (Chow, 1960). Due to the fact that the F statistic is higher to its critical value 2.369 at $1 \%$ level of significance, the study rejects the null hypothesis of structural stability. Therefore, there is a structural change in this model, and it is necessary to split the data into 2 sub-samples, meaning that independent variables have a different impact on both bearer biological assets and consumable biological asset subgroups in the entire sample.

\begin{tabular}{|c|c|c|c|c|c|}
\hline \multicolumn{6}{|c|}{ Panel A: Regression results } \\
\hline \multirow[b]{2}{*}{ Variables } & \multicolumn{2}{|c|}{ Bearer } & & \multicolumn{2}{|c|}{ Consumable } \\
\hline & Coef. & SE & & Coef. & SE \\
\hline Constant & -20.759 & $5.246 * * *$ & & -3.394 & $1.953^{*}$ \\
\hline$B V-B A$ & 0.549 & $0.164^{* * *}$ & & 0.821 & $0.095^{* * *}$ \\
\hline$B A$ & 0.649 & $0.334^{*}$ & & 1.148 & $0.353^{* * *}$ \\
\hline$E$ & 2.497 & $1.038^{* *}$ & & 1.781 & $1.016^{*}$ \\
\hline Dindex $_{1}$ & 3.667 & $2.062^{*}$ & & -0.410 & 0.373 \\
\hline Dindex $_{3}$ & -0.912 & 0.881 & & -0.312 & 0.569 \\
\hline Dindex $_{1} \times B A$ & 4.180 & 3.149 & & -1.239 & 0.900 \\
\hline $\operatorname{Dindex}_{3} \times B A$ & 1.029 & $0.280^{* * *}$ & & 0.040 & 0.345 \\
\hline \multicolumn{6}{|l|}{ Controls } \\
\hline SIZE & 3.745 & $0.838^{* * *}$ & & 0.689 & $0.344^{* *}$ \\
\hline SECTOR $1+$ SECTOR $2=1$ & 1.295 & 1.450 & & -0.012 & 0.513 \\
\hline$N$ & \multicolumn{2}{|c|}{167} & & \multicolumn{2}{|c|}{222} \\
\hline F-stat & \multicolumn{2}{|c|}{ 98.907 } & & \multicolumn{2}{|c|}{$145.717^{* * *}$} \\
\hline Adj. $R^{2}$ & \multicolumn{2}{|c|}{0.866} & & \multicolumn{2}{|c|}{0.878} \\
\hline \multicolumn{6}{|c|}{ Panel B: Chow test of model 3 regression (all, bearer and consumable) } \\
\hline Sum squared residuals & \multicolumn{2}{|c|}{ All } & $\begin{array}{c}\text { Bearer } \\
9880.421\end{array}$ & \multicolumn{2}{|c|}{$\begin{array}{c}\text { Consumable } \\
2285.219\end{array}$} \\
\hline Number of parameters & \multicolumn{2}{|c|}{10} & \multirow{3}{*}{167} & \\
\hline Number of observations & \multicolumn{2}{|c|}{389} & & \multicolumn{2}{|c|}{222} \\
\hline F-statistic $(10,369)$ & 5.7 & & & & \\
\hline
\end{tabular}

*** statistical significance at $1 \%$ level; **statistical significance at 5\% level; *statistical significance at $10 \%$ level

Based on this result, it can be inferred that when recognizing biological assets under fair value, investors make a clear distinction between bearer biological assets and consumable biological assets. To some extent, this evidence supports the recent amendments to IAS 41, which prescribe a different accounting treatment for bearer plants than for other biological assets. 


\section{Conclusions, limitations and suggestions for future research}

A key message from this research is that the empirical evidence regarding value relevance under IAS 41 confirms the recent amendments to this standard, in particular the different behavior of consumable and bearer biological assets in general. This suggests that further academic research, or eventually further IASB projects, could be extended to other bearer biological assets besides plants, in order to determine whether or not to apply the same amendments that are effective for annual periods beginning on or after 1 January 2016.

In brief, there is evidence that the recognized amount of biological assets under the fair value model is value relevant in general. In order to go beyond previous value relevance studies that have dealt only with recognition of biological assets, this study additionally includes the disclosure effect. In this respect, the recognized amount of biological assets under the fair value model is more value relevant for firms that exhibit higher disclosure levels. According to the IAS 41 classification of biological assets, the sample was divided into bearer biological assets and consumable assets. The results are the same, except in the case of consumable biological assets. As far as consumable biological assets are concerned, the interaction variable, which introduces the effect of different disclosure levels in biological asset valuation, is not supported; therefore, it seems that investors value recognized biological assets, but independently from the corresponding disclosure level. One probable explanation would be the fact that there is usually an available market price for consumable biological assets and that these biological assets are usually sold in the short term. Moreover, bearer biological assets are held for an extended period and typically it is more difficult to access the corresponding fair value. Consequently, any further information is useful, so investors value bearer biological assets for firms that exhibit higher disclosure levels of biological assets.

However, there are some limitations to this paper. Firstly, one cannot guarantee that the same results would hold when using a larger sample. In order to assure more robust results regarding panel data, the study should include data from an extended period of time. Using the period between 2011 and 2013 was a possible means to obtain more recent data and to consider a more recent year of IFRS adoption. Further research could replicate this analysis to ascertain whether these results hold consistently across additional countries that had adopted IFRS after 2010. Secondly, with regard to the Ohlson model, there are alternative models to test this data, such as the return model. Additionally, this study has included size and sector as control variables. With this in mind, further research could examine other firm characteristics. On a more narrow level, there is also a subjectivity problem that is intrinsic to the construction and calculation of the disclosure index. For example, deciding which paragraphs of IAS 41 should be grouped and which should represent one index item, as well as deciding if an item is applicable to a specific firm or not. Moreover, it could be useful to investigate the extent to which market assessments of recognized versus disclosed biological asset amounts depend on the method of valuation (historical cost versus fair value).

Finally, given recent amendments to IAS 41 whereby agricultural produce will still be measured at fair value, this change will not completely remove volatility in profit or loss. Initially, bearer plants are recognized at accumulated cost. Depreciation begins once the corresponding asset is in place and ready to work. "The point at which depreciation begins is subjective and is likely to depend on the type of plant. This judgment should be clearly disclosed" (PWC, 2015:6). Firms will need to control biological assets separately under fair valuation from the bearer plants on which they are growing, "which may increase the complexity and subjectivity of the measurement" (Ernst and Young, 2015:11). Consequently, in a couple of years, given the current debate and subsequent amendments that have already been made to IAS 41, it could also be interesting to explore the market valuation implications related to biological assets before and after 2016.

Taking into consideration previous studies, this paper develops an extensive study based on a significant number of different countries with recent data concerning a standard that is currently under discussion. Finally, this paper seeks to help policy makers and international standard setters, involved in any future review of related accounting treatment, to better understand the market valuation implications of this standard in order to improve the level of disclosure by firms, to eliminate ambiguity in interpretation of IAS 41 and to assure greater comparability of information provided by firms.

\section{References}

Ahmed, A., Kilic, E. \& Lobo, G. (2006). Does Recognition versus Disclosure Matter? Evidence from Value relevance of Banks' Recognized and Disclosed Derivative Financial Instruments. Accounting Review, 81, 567-588.

Al Jifri, K. \& Citron, D. (2009). The value relevance of financial statement recognition versus note disclosure: evidence from goodwill accounting. European Accounting Review, 18, 123-140.

Argilés, J., Aliberch, A. \& Blandon, J. (2012). A Comparative Study of Difficulties in Accounting Preparation and Judgement in Agriculture Using Fair Value and Historical Cost for Biological Assets Valuation. Revista de Contabilidad, 15, 109-142. 
Argilés, J., Garcia-Blandón, J., \& Monllau, T. (2011). Fair value versus historical cost-based valuation for biological assets: predictability of financial information. Revista de Contabilidad, 14(2), 87-113.

Baboukardos, G., \& Rimmel, G. (2014). Goodwill under IFRS: Relevance and disclosures in an unfavorable environment. Accounting Forum, 38, 1-17.

Badenhorst, W., Brümmer, L., \& De Wet, J. (2015). The value relevance of disclosed summarised financial information of listed associates. Journal of International Accounting, Auditing and Taxation, 24, 1-12.

Ball, R. (2006). International Financial Reporting Standards (IFRS): pros and cons for investors. Accounting \& Business Research (Wolters Kluwer UK), 36, 5-27.

Black, F. \& Scholes, M. (1973).The Pricing of Options and Corporate Liabilities. Journal of Political Economy 81, 637-54.

Barlev, B. \& Haddad, J. R. (2003). Fair value accounting and the management of the firm. Critical Perspectives on Accounting, 14, 383-415.

Barth, M., \& Clinch, G. (2009). Scale effects in capital markets-based accounting research, Journal of Business Finance and Accounting, 36, 253-88.

Barth, M., \& Clinch, G. (1998). Revalued Financial, Tangible, and Intangible Assets: Associations with Share Prices and Non-Market-Based Value Estimates. Journal of Accounting Research, 36, 199-233.

Barth, M., Clinch, G., \& Shibano, T. (2003). Market Effects of Recognition and Disclosure. Journal of Accounting Research, 41, 581-609.

Barth, M., Beaver, W., \& Landsman, W. (2001). The relevance of the value relevance literature for financial accounting standard setting: another view. Journal of and Economics, 31, 77-104.

Cairns, D. (2006). The Use of Fair Value in IFRS. Accounting in Europe, 3, 5-22.

Choudhary, P. (2011). Evidence on differences between recognition and disclosure: A comparison of inputs to estimate fair values of employee stock options. Journal of Accounting and Economics, 51, 77-94.

Chow , G. (1960). Tests of Equality Between Sets of Coefficients in Two Linear Regressions. Econometrica, 28 (3), 591-605.

Dahmash, F., Durand, R., \& Watson, J. (2009). The value relevance and reliability of reported goodwill and identifiable intangible assets. The British Accounting Review, 41, 120-137.

Elad, C., \& Herbohn, K. (2011). Implementing Fair value accounting in the agricultural sector. Acceded 25 ${ }^{\text {th }}$ November 2014, <http://icas.org.uk/res/elad_report_feb_2011.pdf>

Ernst and Young (2015). "IFRS update of standards and interpretations in issue at 31 March 2015". Last accessed on 200 $0^{\text {th }}$ August 2015, $<$ http://www.ey.com/Publication/vwLUAssets/IFRS_Update_of_standards_and_interpretations_in_issue_at_31_March_2015./\$File/CT ools-Update-March2015.pdf>

Fargher, N. \& Zhang, J. Z. (2014). Changes in the measurement of fair value: Implications for accounting earnings. Accounting Forum, 38, 184-199.

Fried, A. (2012). Disclosure versus recognition: Evidence from lobbying behavior in response to SFAS No. 158. Research in Accounting Regulation, 24, 25-32.

Gabriel, N., \& Stefea, P. (2013). International Accounting Standard 41 (IAS 41) - implication for reporting crop assets. Lucrări Științifice Management Agricol, 15(3), 100-105

Gastón, S., García, C., Jarne, J., \& Laínez Gadea, J. (2010). IFRS adoption in Spain and the United Kingdom: Effects on accounting numbers and relevance. Advances in Accounting, 26(2), 304-313.

Greene, W. (2012). Econometric Analysis ( $7^{\text {th }}$ ed.). New York University. Prentice Hall.

Gujarati, D. (1995). Basic Econometrics ( $3^{\text {rd }}$ ed.). McGraw-Hill International editions.

Hamberg, M., \& Beisland, L. (2014). Changes in the value relevance of goodwill accounting following the adoption of IFRS 3. Journal of Accounting, Auditing and Taxation,23 (2), 59-73.

Hitz, J.-M. (2007). The Decision Usefulness of Fair Value Accounting - A Theoretical Perspective. European Accounting Review, 16, 323362.

Holthausen, R. \& Watts, R. (2001). The relevance of the value relevance literature for financial accounting standard setting. Journal of Accounting and Economics, 31, 3-75.

Huffman, A. (2013). Value relevant asset measurement and asset use: Evidence from IAS 41. Acceded $25^{\text {th }}$ November 2014, $<$ http://eifrs.ifrs.org/eifrs/comment_letters/27/27_3206_AdriennaHuffmanUniversityofUtah_2_HuffmanAdriennaJobMarketPaper.pdf >

International Accounting Standard (IAS) 16 - Property, plant and equipment. Available at http://www.ifrs.org

International Accounting Standard (IAS) 41 - Agriculture. Available at http://www.ifrs.org

International Financial Reporting Standard (IFRS) 13 - Fair value measurement. Available at http://www.ifrs.org

Kun, Y. (2013). Does Recognition versus Disclosure Affect Value Relevance? Evidence from Pension Accounting. Accounting Review, 88, $1095-1127$.

Laux, C., \& Leuz, C. (2009). Did fair-value accounting contribute to the financial crisis? Journal of Economic Perspectives (forthcoming), Acceded $25^{\text {th }}$ November 2014, < http://ssrn.com/abstract=1487905 >

Lefter, V., \& Roman, A. (2007). IAS 41: fair value accounting, Theoretical and Applied Economics 5 (510), 15-22.

Littleton, A. (1935). "Value or Cost." The Accounting Review 10(3): 269-273.

Lourenço, I., \& Curto, J. (2008). The Value Relevance of Investment Property Fair Values. Acceded 25 $5^{\text {th }}$ November 2014, $<$ http://ssrn.com/abstract=1301683 >

Lopes, P., \& Rodrigues, L. (2007). Accounting for financial instruments: An analysis of the determinants of disclosure in the Portuguese stock exchange. The International Journal of Accounting, 42, p.25-56

Machado, M., Martins, E., \& Carvalho, L. (2015). Reliability in fair value of assets without an active market. Advances in Scientific and Applied Accounting, 7(3), 319-338.

Mala, R., \& Chand, P. (2012). Effect of the global financial crisis on accounting convergence. Accounting \& Finance, 52, 21-46.

Martins, A., Almeida, R. \& Jesus, T. (2012). O Impacte da IAS 41 e o seu valor relevante nas empresas agrícolas cotadas. Revista Portuguesa de Contabilidade, II (8), 577-616

Ohlson, J. (1995). Earnings, book value and dividends in security valuation. Contemporary Accounting Research, 11, 611-687.

Oliveira, L., Rodrigues, L., \& Craig, R. (2010). Intangible assets and value relevance: Evidence from the Portuguese stock exchange. The British Accounting Review, 42, 241-252.

Owusu-Ansah, S. (1998). The impact of corporate attributes on the extent of mandatory disclosure and reporting by listed companies in Zimbabwe. The International Journal of Accounting, 33(5), 605-631. 
PWC (2015). “IFRS news - May 2015”. Last accessed on $20^{\text {th }}$ August 2015, http://www.pwc.com/en_IM/IM/publications/assets/ifrs-news-may-2015.pdf

PWC (2011). IAS 41, Agriculture: the fair value of standing timber: 2011 update. 25 ${ }^{\text {th }}$ November 2014 , <http://www.pwc.com/gx/en/forest-paper-packaging/publications/ias41-fair-value-timber.jhtml>

Santos, E., Ponte, V., \& Mapurunga, P. (2013). Mandatory IFRS adoption in Brazil (2010): Index of Compliance with Disclosure Requirements and Explanatory Factors of Firms Reporting. Acceded 25 ${ }^{\text {th }}$ November 2014, < http://dx.doi.org/10.2139/ssrn.2310625>

Silva, R., Figueira, L., Pereira, L., \& Ribeiro, M. (2012). Process of Convergence to the International Financial Reporting Standards: An Analysis of the Disclosure Requirements of CPC 29/IAS 41. Acceded 25 ${ }^{\text {th }}$ November 2014, <http://dx.doi.org/10.2139/ssrn.2012705>

Silva Filho, A., Machado, M., \& Machado, M. (2013). Historical cost X fair value: which information is more relevant on the measurement of biological assets? Custos e @gronegócio on line - v. 9, n. 2 - Apr/Jun - 201, 27-50.

Silva Filho, A., Martins, V., \& Machado, M. (2013). Adoption of fair value for biological assets: analysis of its relevance in brazilian companies. Revista Universo Contábil, ISSN 1809-3337 Blumenau, v. 9, n. 4, out./dez., 2013, 110-127.

Tsalavoutas I., André, P., \& Dionysiou, D. (2014). "Worldwide application of IFRS 3, IAS 38 and IAS 36, related disclosures, and determinants of non-compliance”, ACCA Research report 134, Certified Accountants Educational Trust (London)

Tsalavoutas I., \& Dionysiou, D. (2014). Value relevance of IFRS mandatory disclosure requirements. Journal of Applied Accounting Research, $15,22-42$.

Tsoligkas, F. \& Tsalavoutas, I. (2011). Value relevance of R\&D in the UK after IFRS mandatory implementation. Applied Financial Economics, 21, 957-967.

White, H. (1980). A heteroskedasticity-consistent covariance matrix estimator and a direct test for heteroskedasticity. Econometrica, 48(4), 817-838. 